\title{
ADAPTIVE AND CROSS-PROTECTIVE RESPONSES AGAINST CADMIUM AND ZINC TOXICITY IN CADMIUM-RESISTANT BACTERIUM ISOLATED FROM A ZINC MINE
}

\author{
Benjaphorn Prapagdee*, Anchulee Watcharamusik
}

\begin{abstract}
Laboratory of Environmental Biotechnology, Faculty of Environment and Resource Studies, Mahidol University, Salaya, Nakhonpathom 73170, Thailand.
\end{abstract}

Submitted: August 03, 2008; Returned to authors for corrections: September 24, 2008; Approved: May 21, 2009.

\begin{abstract}
Cadmium $(\mathrm{Cd})$ is a major environmental hazard, which usually is detected in its ionic form of $\mathrm{Cd}^{2+}$. It also causes adverse toxic effects on human health and other living organisms. Cd-resistant bacteria were isolated from Cd-contaminated soils. One isolate, TAK1, was highly resistance level to Cd toxicity. TAK1 was isolated from soil contaminated with a high $\mathrm{Cd}$ concentration $\left(204.1 \mathrm{mg} . \mathrm{kg}^{-1}\right)$. The result of $16 \mathrm{~S}$ rDNA sequence analysis found that the TAK1 showed the similarity to Ralstonia sp. Physiological adaptive and cross-protective responses to $\mathrm{Cd}$ and $\mathrm{Zn}$ killing were investigated in Ralstonia sp.TAK1. Exposure to a low concentration of $\mathrm{Cd}$ induced adaptive resistance to higher concentrations of $\mathrm{Cd}$. In addition, pretreatment of Ralstonia sp.TAK1 with an inducing concentration of Cd conferred crossprotective response against subsequent exposure to the lethal concentrations of $\mathrm{Zn}$. The induced adaptive and cross-protective response Ralstonia sp.TAK1 required newly synthesized protein(s). Cd-induced adaptive and cross-protective responses against $\mathrm{Cd}$ and $\mathrm{Zn}$ toxicity are the important mechanisms used by Ralstonia sp.TAK1 to survive in the heavy metal contaminated environments. These findings might lead to the use of Ralstonia sp.TAK1 for microbial based remediation in $\mathrm{Cd}$ and $\mathrm{Zn}$-contaminated soils.
\end{abstract}

Key words: Bacterial responses; Cadmium; Zinc; Metal Resistance; Ralstonia sp.

\section{INTRODUCTION}

Cadmium (Cd), classified as a heavy metal, is widely distributed in the earth's crust. It is commonly regarded as a pollutant of worldwide concern $(1,16)$. High $\mathrm{Cd}$ concentration in soil is more commonly found in areas containing deposits of zinc, lead and copper ores. Weathering results in the riverine transport of $\mathrm{Cd}$ into the oceans and represents a major flux of the global $\mathrm{Cd}$ cycle. $\mathrm{Cd}$ has been intentionally and accidentally released into the environment by industrial and agricultural activities, causing serious environmental problems. The activities involved in the mining, production and consumption of $\mathrm{Cd}$ and other nonferrous metals results in the release of significant quantities of $\mathrm{Cd}$ into the environment (15). In addition, the intensive application of phosphate fertilizers in the agricultural areas increased the level of $\mathrm{Cd}$ accumulation in soils $(22,34,35)$.

Discharge of $\mathrm{Cd}$ into the environment causes direct and

*Corresponding Author. Mailing address: Faculty of Environment and Resource Studies, Mahidol University, Salaya, Nakhonpathom 73170, Thailand.; Tel: 6624415000 ext.1319 Fax: 6624419509 to 10.; E-mail: enbrp@mahidol.ac.th 
indirect effects on microorganisms. $\mathrm{Cd}$ is well-known for being highly toxic to soil microorganisms even at very low concentrations. $\mathrm{Cd}$ can enter the cell through divalent cation uptake systems $\left(\mathrm{Zn}^{2+}, \mathrm{Ca}^{2+}, \mathrm{Mn}^{2+}\right)(25)$. The effects of $\mathrm{Cd}$ exposure have been investigated in many microorganisms (4, 31). Cd has been reported in field studies to be responsible for changes in species composition in microbial populations (16). However, trace amounts of some metals such as Zn, Co and $\mathrm{Ni}$ are essential for microbial metabolic pathways. When the concentration of these essential metals exceeds the required amount, they become highly toxic to microorganisms (23). The exposure of microorganisms to excessive concentrations of metals adversely affects their growth, morphology and biochemical activity $(8,14,18,30)$.

Microorganisms have several resistant mechanisms that can prevent heavy metal toxicity either by inducing development of tolerance or resistance. The general heavy metal resistance mechanisms are an active metal efflux, synthesis of metal-binding peptides, proteins or polysaccharides such as metallothioneins, extracellular polymeric substance (EPS) and the increasing of detoxification enzymes expression (13). Heavy metal resistance is known to occur in many bacterial genera. Bacteria use various types of resistance mechanisms in response to heavy metal toxicity.

In heavy metal contaminated sites, soil bacteria are usually exposed to heavy metals resulting in the establishment of heavy metal-resistant bacterial populations $(11,27)$. Heavy metals are able to induce increased resistance levels in soil bacteria and modify bacterial responses to environmental conditions either by inducing mutations or by altering physiological responses (38). Generally, exposure of bacteria to a low dose of one stress can induce a subsequent increase in resistance to the same (adaptive) or unrelated (cross protection) stress (20).

Presently, little is known regarding the protective responses of soil bacteria to $\mathrm{Cd}$ toxicity. These responses are an important strategy for bacterial survival in Cd-polluted environment. A better understanding of the bacterial responses to heavy metals toxicity could be helpful for bioremediation of heavy metal contaminated sites. For this study, Cd-resistant bacteria were isolated from $\mathrm{Cd}$ contaminated soils at a zinc mine and examined for $\mathrm{Cd}$ resistance. Consequently, we investigated the ability of $\mathrm{Cd}$ to induce adaptive and cross-protective responses to $\mathrm{Cd}$ and $\mathrm{Zn}$ killing in Cd-resistant bacteria.

\section{MATERIALS AND METHODS}

\section{Soil sampling and analysis of $\mathrm{Cd}$ concentration in contaminated soil}

Five composite soil samples were collected from the top $10 \mathrm{~cm}$ of soil surface horizon at zinc mine located near Maetao Creek in Tak province, Thailand. High concentrations of $\mathrm{Cd}$ in soil, water and sediment in this area have been previously reported by Department of Primary Industries and Mines, Ministry of Industry, Thailand in year 2005. Collected soil samples were analyzed for $\mathrm{Cd}$ concentrations by atomic adsorption spectrometry (AAS) as described previously (26).

\section{Isolation and identification of Cd-resistant bacteria}

Cd-resistant bacteria were counted and isolated by using a modification of the plate sensitivity assay described previously by Delaunay et al. (9). Briefly, serial 10-fold dilutions of soil suspensions were plated onto minimal salt medium (MSM) (31) amended with $4 \mathrm{mM} \mathrm{CdCl}_{2}$ (Fluka, Switzerland). The plates were incubated at $28^{\circ} \mathrm{C}$ and inspected regularly for bacterial colonies. Only colonies from the highest concentration of $\mathrm{Cd}$ were selected for further study based on differing colony morphology. Bacterial colonies were streaked on fresh Cd-amended MSM plate. Bacterial numbers in soil samples were enumerated using R2A agar plates (Difco, USA).

Pure culture of Cd-resistant bacterial isolate was identified by the analysis of 16S rDNA sequencing (28) using universal primers of $27 \mathrm{f}$ ( $5^{\prime}$-AGA GTT TGA TCC TGG CTC AG -3') and 1525r (5'-AAG GAG GTG ATC CAG CC-3'). 
Prapagdee, B. et al.

The fragment of $16 \mathrm{~S}$ rDNA was amplified in a Thermocycler (PE Applied Biosystems, USA). The nucleotide sequence of $16 \mathrm{~S}$ rDNA was determined by $\mathrm{ABI}$ PRISM BigDye ${ }^{\mathrm{TM}}$ Terminator Cycle Sequencing Ready Reaction Kit with sequencing enzyme AmpliTaq DNA polymerase from Applied Biosystems (ABI, USA). The 16S rDNA sequence of selected bacterial isolate was analyzed by using BLAST program (2) from NCBI database.

\section{Bacterial growth condition}

All bacterial strains were maintained on tryptic soy agar (TSA) (Difco, USA) plates. For the experiment, all bacteria strains were aerobically cultivated in $\mathrm{TSB}$ at $28^{\circ} \mathrm{C}$ with continuous shaking at $120 \mathrm{rpm}$. Overnight cultures were inoculated into fresh TSB to give an $\mathrm{OD}_{600}$ of about 0.1 . Bacteria in the exponential phase $\left(\mathrm{OD}_{600}\right.$ about 0.5 , after $4 \mathrm{~h}$ of growth) were used in all experiments, as indicated.

\section{Determination of Cd-resistance levels in Cd-resistant bacteria}

Analysis of the killing effects of $\mathrm{Cd}$ on Cd-resistant bacteria was performed by the use of inhibition zone assay (19). Briefly, exponential phase bacteria $\left(\mathrm{OD}_{600} \sim 0.5\right.$ after growth $4 \mathrm{~h}$ ) were mixed with $10 \mathrm{ml}$ of pre-warmed $\left(50^{\circ} \mathrm{C}\right)$ top agar (MSM containing $0.7 \%$ agar) and overlaid on the top of MSM agar plates (14 cm diameter petri-dishes and poured with $50 \mathrm{ml}$ of MSM agar). The agar plates were left at room temperature for $15 \mathrm{~min}$ to let the top agar solidify. Five $\mu \mathrm{l}$ of $3 \mathrm{M} \mathrm{CdCl}_{2}$ was applied to $5-\mathrm{mm}$ diameter paper discs made from Whatman filter paper and subsequently placed on the lawn of bacteria. The diameters of growth inhibition zones were measured after an overnight incubation at $28^{\circ} \mathrm{C}$.

\section{Determination of $\mathrm{Cd}$-inducible responses against $\mathrm{Cd}$ and}

\section{Zn toxicity}

Cd-induced adaptive and cross-protective experiments in Cd-resistant bacterium were performed by survival curve determination according to some modification method described by Vattanaviboon et al. (36) and Vattanaviboon and Mongkolsuk (37). Bacterial culture was grown in TSB at $28^{\circ} \mathrm{C}$ with shaking for $3 \mathrm{~h}$ (exponential-phase culture) and subsequently induced with $400 \mu \mathrm{M} \mathrm{CdCl}_{2}$. This culture was grown for an additional $30 \mathrm{~min}$ before aliquots of cells were removed and treated with lethal concentrations of $\mathrm{CdCl}_{2}(50$, $100,150$ and $200 \mathrm{mM})$ and $\mathrm{ZnCl}_{2}(100,200,300$ and 400 $\mathrm{mM}$ ) for $30 \mathrm{~min}$. After treatment, the cells were removed and washed once with fresh TSB medium before determination of cell survival by plating appropriate dilutions on TSA plates. Colonies were counted after $48 \mathrm{~h}$ of incubation at $28^{\circ} \mathrm{C}$. The percent survival was defined as the number of $\mathrm{CFU}$ recovered after treatment divided by the number of colony forming unit (CFU) prior to treatment multiplied by 100 .

\section{Investigation of the nascent polypeptide synthesis involved in the adaptive and cross-protective responses to} Cd and Zn toxicity

To investigate $\mathrm{Cd}$-induced adaptive and cross protective resistance required newly synthesized proteins, the induction experiments were repeated. However, $100 \mu \mathrm{g} / \mathrm{ml}$ of chloramphenicol $(\mathrm{Cm})(20)$, a protein synthesis inhibitor, was added to Ralstonia sp. TAK1 culture prior to pretreatment with $400 \mu \mathrm{M} \mathrm{CdCl}$. The induced and uninduced cultures were then treated with lethal concentrations of $\mathrm{CdCl}_{2}$ or $\mathrm{ZnCl}_{2}$ to investigate the adaptive and cross-protective resistance as mentioned above.

\section{Statistical analysis}

All experiments were independently repeated at least three times. The significance of the differences observed when comparing two strains was determined statistically using Student's t-test, one-way analysis of variance (ANOVA). The posthoc pairwise comparison with a least significant difference test at $\mathrm{p} \leq 0.05$ was used when more than two strains were compared. 


\section{RESULTS}

\section{Cd-resistant bacteria isolated from $\mathrm{Cd}$-contaminated soils}

Five samples of metal-polluted soils were collected from the different locations of the zinc mine and in the vicinity of a paddy field. Cd concentrations in soil samples ranged from 36.2 to $204.1 \mathrm{mg} \cdot \mathrm{kg}^{-1}$ of soil (Table 1). The levels of $\mathrm{Cd}$ in the most of soil samples, but not in the soil sample collected from sampling site 4 , were found to be above the permissible limits of soil quality standard for agricultural use in Thailand (not to exceed $37 \mathrm{mg} \cdot \mathrm{kg}^{-1}$ of soil) (21). The highest $\mathrm{Cd}$ concentration in the soil was found at sampling site $1 . \mathrm{Cd}$ contamination in soil even at low concentration causes a detrimental effect on the survival of soil microorganisms. The effects of $\mathrm{Cd}$ on microbial population in the environment have been so far lacking study. The culturable bacterial population sizes in the soil samples were determined by plating appropriate dilutions onto R2A medium. The result showed that culturable bacterial number in soil sample collected from sampling site 1 was lower than that of other soil samples (Table 1) due to the high concentration of $\mathrm{Cd}$ stress imposed in the soil. This result indicated that $\mathrm{Cd}$ toxicity adversely affected the quantity of viable soil bacteria.

Cd-resistant bacteria in Cd-contaminated soils were counted and isolated by plating soil suspensions on MSM amended with $4 \mathrm{mM} \mathrm{CdCl}_{2}$. High numbers of Cd-resistant bacteria $\left(3.5 \times 10^{4}\right.$ CFU.g ${ }^{-1}$ of dry soil) were found in the soil sample collected from the sampling site 1 (Table 1) which was associated with the effect of higher concentration of $\mathrm{Cd}$ in soil. Significant numbers of Cd-resistant bacteria were not found in other soil samples (Sampling sites 2 to 5). This evidence suggested that differences in the number of $\mathrm{Cd}$ resistant bacteria among the soils were only observed at higher levels of $\mathrm{Cd}$ concentration. In addition, the six isolates of Cd-resistant bacteria from culturable bacteria on $\mathrm{Cd}$ amended MSM plates were chosen for further study based on their colony morphology and their potential to grow on MSM plate supplemented with $4 \mathrm{mM} \mathrm{CdCl}$.
Table 1. Effects on cadmium contaminated in soils on the number of viable cells and Cd-resistant bacteria

\begin{tabular}{|c|c|c|c|}
\hline $\begin{array}{l}\text { Soil } \\
\text { samples }\end{array}$ & $\begin{array}{l}\text { Cd Conc. } \\
\left(\mathrm{mg} \cdot \mathrm{kg}^{-1}\right)\end{array}$ & $\begin{array}{c}\text { Total viable bacteria }{ }^{a} \\
\text { (CFU.g }{ }^{-1} \text { dry soil) }\end{array}$ & $\begin{array}{c}\text { Cd-resistant bacteria }{ }^{b} \\
\text { (CFU.g }{ }^{-1} \text { dry soil) }\end{array}$ \\
\hline 1 & 204.1 & $5.2 \times 10^{5}$ & $3.5 \times 10^{4}$ \\
\hline 2 & 38.6 & $4.3 \times 10^{7}$ & $2.2 \times 10^{3}$ \\
\hline 3 & 48.3 & $2.2 \times 10^{7}$ & $1.9 \times 10^{3}$ \\
\hline 4 & 36.2 & $3.9 \times 10^{7}$ & $2.9 \times 10^{3}$ \\
\hline 5 & 78.2 & $1.3 \times 10^{7}$ & $4.1 \times 10^{3}$ \\
\hline
\end{tabular}

${ }^{a}$ Soil samples were plated onto R2A medium

${ }^{\mathrm{b}}$ Soil samples were plated onto MSM amended with $4 \mathrm{mM} \mathrm{CdCl}$

\section{The levels of $\mathrm{Cd}$ resistance in soil bacteria}

The resistance levels against $\mathrm{Cd}$ toxicity were determined in the exponential-phase cultures of the six bacterial isolates using the growth inhibition zone assay. The result clearly revealed that the TAK1 isolated from soil sample at sampling site 1 was highly resistant to $3 \mathrm{M} \mathrm{CdCl}_{2}$ toxicity (clear zone diameter $13.8 \mathrm{~mm}$ ) as compared to other isolates. This result implied that bacteria isolated from highly Cd-contaminated soil exhibited higher $\mathrm{Cd}$ resistance levels than bacteria isolated from uncontaminated soil. Some Cd-resistant bacterial strains increase resistance under higher levels of $\mathrm{Cd}$ toxicity because $\mathrm{Cd}$ could induce the alteration in the bacterial response or resistance mechanisms.

From the morphological study, the TAK1 is Gram-negative and short-rod shape. Its colony on TSA plate was creamcolored, smooth, rounded-margin and butyrous or viscid. The colony diameter was 4-5 $\mathrm{mm}$ after incubation for $24 \mathrm{~h}$. Using 16S rDNA sequencing, the Cd-resistant bacterium, the TAK1, showed 96\% similarity to Ralstonia sp. from GenBank database accession number AB167178. Thus, the isolate TAK1 could be identified as Ralstonia sp.

Cd-induced adaptive and cross-protective responses to $\mathrm{Cd}$ and $\mathrm{Zn}$ toxicity and required nascent synthesized polypeptide(s) 
Inducible protective responses to $\mathrm{Cd}$ toxicity are an important response for soil bacteria. The effect of $\mathrm{Cd}$ pretreatment on Ralstonia sp. TAK1 physiological responses to $\mathrm{Cd}$ killing treatment was investigated. The exponential phase cells were challenged with an inducing concentration of $\mathrm{CdCl}_{2}$ at $400 \mu \mathrm{M}$ for $30 \mathrm{~min}$ before being treatments with various concentrations of $\mathrm{CdCl}_{2}$ at $0,50,100,150$ and 200 $\mathrm{mM}$ for $30 \mathrm{~min}$. The results clearly showed that exposure to sub-lethal concentrations of $\mathrm{Cd}$ induced adaptive protection to a subsequent treatment with higher, normally lethal concentrations of $\mathrm{Cd}$ (Fig.1A). Cd-induced cells were 10-fold more resistant to $200 \mathrm{mM} \mathrm{CdCl}_{2}$ than the un-induced control cells. The results indicated that challenging of Ralstonia sp.TAK 1 cells with a sub-lethal concentration of $\mathrm{Cd}$ was able to induce adaptive protection to subsequent killing treatments with Cd.

Experiments were then performed to find out whether
Cd-induced cells had resistance to other metals, particularly $\mathrm{Zn}$. The Cd-induced cells were treated with various concentrations of $\mathrm{ZnCl}_{2}$ at 100, 200, 300 and $400 \mathrm{mM}$ for 30 min. Interestingly, Cd-induced cells were more than 250 -fold more resistant to subsequent killing treatments with $400 \mathrm{mM}$ $\mathrm{ZnCl}_{2}$ (Fig.1B). These data indicated that $\mathrm{Cd}$ could induce the cross-protective response to $\mathrm{Zn}$ toxicity. In addition, the results found that the adaptive and cross-protective responses to $\mathrm{Cd}$ and $\mathrm{Zn}$ in Ralstonia sp.TAK1 were eliminated by the presence of $\mathrm{Cm}$ in culture broth. The percentages of survival cells after treatment with high concentrations of $\mathrm{CdCl}_{2}$ (Fig.1A) and $\mathrm{ZnCl}_{2}$ (Fig.1B) were significantly decreased when $\mathrm{Cm}$ was added prior to an induction treatment. These results suggested that $\mathrm{Cd}$ and $\mathrm{Zn}$-induced adaptive and crossprotection responses against $\mathrm{Cd}$ and $\mathrm{Zn}$ toxicity required newly synthesize protein(s).
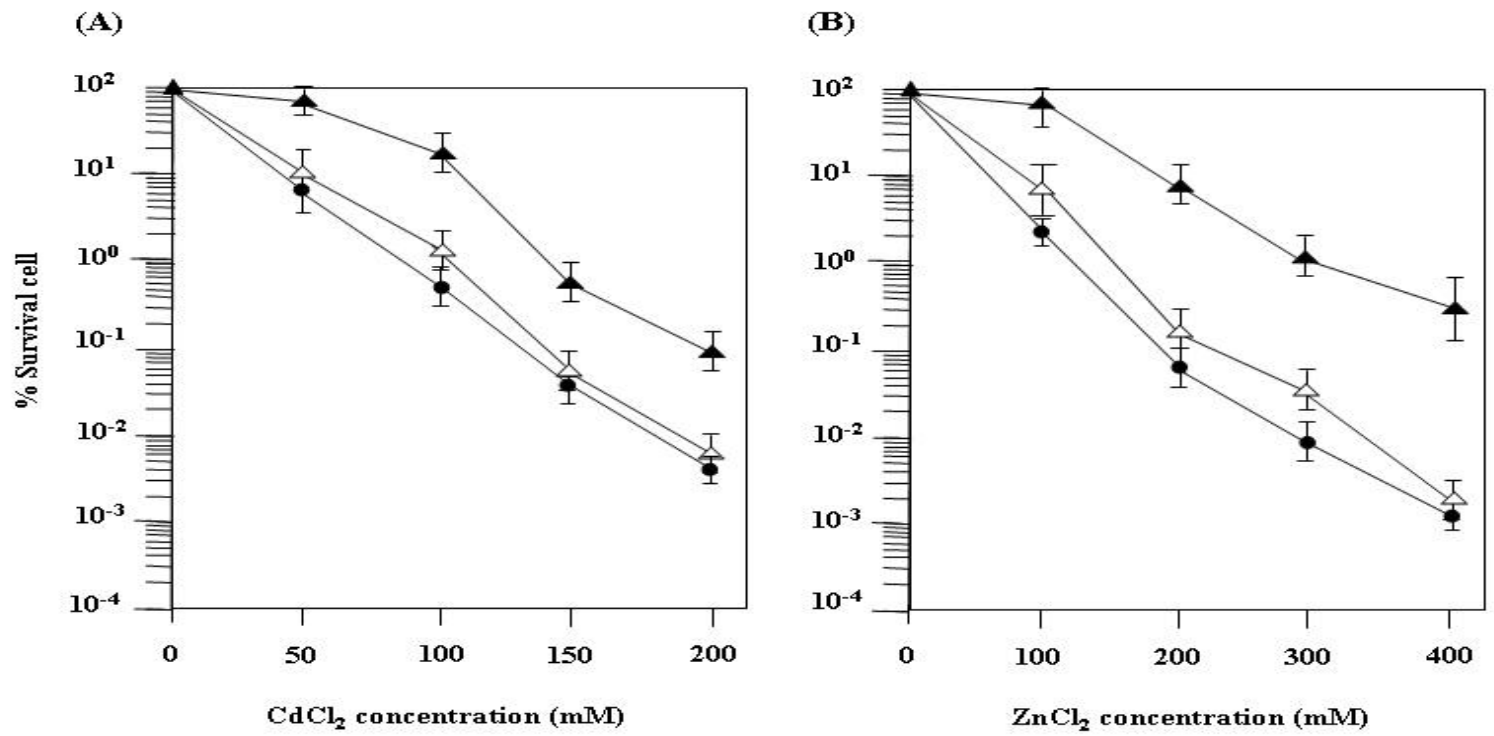

Figure 1. Cd-induced adaptive and cross-protective responses to $\mathrm{Cd}$ and $\mathrm{Zn}$ killing in Ralstonia sp. TAK1 and the involvement in the nascent protein(s) synthesis Ralstonia sp.TAK1 was grown aerobically in TSB broth. Cd induction and killing treatment with $\mathrm{Cd}$ and $\mathrm{Zn}$ were performed as described in materials and methods. The survival curves of exponential phase cultures of Ralstonia sp.TAK1 were pretreated with $\mathrm{CdCl}_{2}$ as Cd-induced cells $(\boldsymbol{\Delta})$, uninduced cells $(\Delta)$ and $\mathrm{Cd}$ induced in the presence of chloramphenicol (-) and then exposed to the high concentrations of $\mathrm{CdCl}_{2}(\mathrm{~A})$ and $\mathrm{ZnCl}_{2}(\mathrm{~B})$ at indicated concentrations. The values presented are mean and standard deviation of three replicates. 


\section{DISCUSSION}

High Cd contamination in soil is a characteristic feature around non-ferrous metal mines and smelters, particularly in the case of those handling zinc ores. The mining of zinc ore has further increased the extent of Cd contamination (15). In unpolluted areas, Cd concentration in surface soil has been reported to be in the range between 0.2 and $0.4 \mathrm{mg} \cdot \mathrm{kg}^{-1}$ of soil. However, higher Cd in soils, up to $160 \mathrm{mg} \cdot \mathrm{kg}^{-1}$ of soil, was occasionally found (16). Cd shows toxic effects on a wide range of microorganisms and the resulting chronic metal stress decreases the bacterial number, diversity and activity $(12,15,31)$.

$\mathrm{Cd}$, a non-redox-reactive heavy metal, was able to displace $\mathrm{Zn}$ and $\mathrm{Fe}$ ions in proteins resulting in inactivation and release of free ferrous ions $\left(\mathrm{Fe}^{2+}\right)$ that can catalyze the generation of reactive oxygen species via Fenton reaction (33). Thus, Cd toxicity is also involved in oxidative damage in many microorganisms (6). However, $\mathrm{Cd}$ is able to induce the expression of genes and many regulons including genes directly responsible to metal transporters $(3,5,24)$. The metal transporter in bacteria involved in $\mathrm{Cd}$ resistance mechanisms as well as Cd toxicity is also sequestered by EPS. Several investigators have reported that bacterial communities in highly metal-contaminated soil are more resistant than uncontaminated soil communities $(10,27,31)$. Culturable numbers of Cd-resistant bacteria in $\mathrm{Cd}$ contaminated soil were higher than that in uncontaminated soil (31). The development of metal resistant populations and metal resistance levels are directly proportional to the concentrations of metal exposure $(29,30)$.

As stated by Castro-Silva et al. (7), bacteria isolated from the coal mining environment exhibited the highly resistant to $\mathrm{Ni}$ and $\mathrm{Zn}$ but they were not resist to $\mathrm{Cd}$. Normally, resistance to $\mathrm{Cd}$ is more prevalent in Gram-negative bacteria than Gram-positive bacteria. Thus, most bacteria isolated from metal-contaminated arable soils are Gram-negative (27). Ralstonia sp. TAK1, a Gram-negative bacterium, showed high resistance against $\mathrm{Cd}$ toxicity. It was found that the highest amount of exopolymer or EPS production was found at the stationary phase of growth (data not shown). Thus, resistance mechanism to $\mathrm{Cd}$ in the isolate TAK 1 probably involves an EPS production. EPS is able to bind potentially toxic metals as metal-EPS complexes and is thought to be important in controlling metals distribution in the environment (13). Iyer et al. (17) reported that EPS produced by Enterobacter cloaceae could adsorb heavy metals due to its metal chelating property. High resistance to various heavy metals and high metal chelating ability of bacteria could provide a potential application of either the bacterial cells or microbial components for bioremediation of metalcontaminated soils, sediments and waters.

On the other hand, the Cd-resistance mechanism in Ralstonia sp.TAK1 might include ion efflux pumps. In Gram-negative bacteria, CzcABC protein complex is the efflux pump system for divalent cations namely, $\mathrm{Cd}^{2+}, \mathrm{Zn}^{2+}$, $\mathrm{Co}^{2+}$ (23). CzcABC protein complex is three polypeptides membrane-bound protein complex that functions as a chemiosmotic divalent cation-proton antiporter, not an ATPase (32). In addition to CzcABC, this efflux system contains $\mathrm{CzcD}$ and $\mathrm{CzcR}$ which are required for the regulation of $c z c A B C$ expression (23). This system mediates resistance to $\mathrm{Cd}$ in the metal resistant bacterium Ralstonia metallidurans $\mathrm{CH} 34$ (previously known as Alcaligenes eutrophus) (24).

Inducing Ralstonia sp.TAK1 with a sub-lethal concentration of $\mathrm{Cd}$ exhibited the adaptive and crossprotective responses to subsequent killing treatments with $\mathrm{Cd}$ and $\mathrm{Zn}$, respectively. These protective responses to $\mathrm{Cd}$ and Zn killings in Ralstonia sp.TAK1 probably involve ion efflux pumps. Cd was able to stimulate the expression of $c z c A B C$ operon that is involved in the metal efflux pump system (24). In Xanthomonas campestris, Cd-induced cells showed the adaptive and cross-protective responses against subsequent exposure to higher concentrations of $\mathrm{Cd}$ and $\mathrm{Zn}$, respectively (4). In addition, it has been reported that the induced adaptive and cross-protective resistance against stresses in microbes required nascent protein synthesis (20). Cd and $\mathrm{Zn}$-induced 
adaptive and cross-protection responses against $\mathrm{Cd}$ and $\mathrm{Zn}$ toxicity in Ralstonia sp.TAK1 involved in the synthesis of newly protein(s). The requirement for nascent polypeptide synthesis implies that $\mathrm{Cd}$ is able to induce expression of genes involved in metal toxicity protective pathways. The synthesis of new protein(s) by Cd induction was also reported in $X$. campestris (4). The adaptive and cross-protective responses against metal toxicity are important mechanisms for bacterial survival in metal polluted environments.

\section{ACKNOWLEDGEMENTS}

The authors thank S. Pinrod, N. Khondee and W. Chotnok for technical assistance and Edward A. Grand for a critical reading of this manuscript. This research work was supported by a Young Research Scholar Grant from Mahidol University, Thailand to B.Prapagdee.

\section{REFERENCES}

1. Alloway, B.J. (1995). Heavy Metals in Soil. $2^{\text {nd }}$ ed., Blackie Academic \& Professional, London, pp.38-52.

2. Altschul, S.F.; Madden, T.L.; Schäffer, A.A.; Zhang J.; Zhang, Z.; Miller, W.; Lipman, D.J. (1997). Gapped BLAST and PSI-BLAST: a new generation of protein database search programs. Nucleic Acids Res., 25, 3389-3402.

3. Anton, A.; Grosse, C.; Reissmann, J.; Pribyl, T.; Nies, D.H.; (1999). $\mathrm{CzcD}$ is a heavy metal ion transporter involved in regulation of heavy metal resistance in Ralstonia sp. strain CH34. J. Bacteriol., 181, 68766881.

4. Banjerdkij, P.; Vattanaviboon, P.; Mongkolsuk, S. (2003). Cadmiuminduced adaptive resistance and cross-resistance to zinc in Xanthomonas campestris. Curr. Microbiol., 47, 260-262.

5. Binet, M. R.; Poole, R.K. (2000). Cd(II), Pb(II) and $\mathrm{Zn}$ (II) ions regulate expression of the metal-transporting P-type ATPase ZntA in Escherichia coli. FEBS Lett. 473, 67-70.

6. Brennan, R. J.; Schiestl, R.H. (1996). Cadmium is an inducer of oxidative stress in yeast. Mutat. Res. 356, 171-178.

7. Castro-Silva, M.A.; Lima, A.O.S.; Gerchenski, A.V.; Jaques, D.B.; Rodrigues A.L.; Souza, P.L.; Rörig, L.R. (2003). Heavy metal resistance of microorganisms isolated from coal mining environments of Sata Catarina. Braz. J. Microbiol., 34(Suppl.1), 45-47.

8. Dean-Ross, D.; Mills, A.L. (1989). Bacterial community structure and function along a heavy metal gradient. Appl. Environ. Microbiol., 55,
2002-2009.

9. Delaunay, A.; Pflieger, D.; Barrault, M.B.; Vinh, J.; Toledano, M.B.; (2002). A thiol peroxidase is an $\mathrm{H}_{2} \mathrm{O}_{2}$ receptor and redox-transducer in gene activation. Cell, 111, 471-481.

10. Diaz-Ravin, M.; Baath, E. (1996). Development of metal tolerance in soil bacterial communities exposed to experimentally increased metal levels. Appl. Environ. Microbiol., 62, 2970-2977.

11. Ellis, R.J.; Morgan, P.; Weightman, A.J.; Fry, J.C. (2003). Cultivationdependent approaches for determining bacterial diversity in heavymetal-contaminated soil. Appl. Environ. Microbiol., 69, 3223-3230.

12. Frostegard, A.; Tunlid, A.; Baath, E. (1993). Phospholipid fatty acid composition, biomass, and activity of microbial communities from two soil types experimentally exposed to different heavy metals. Appl. Environ. Microbiol., 59, 3605-3617.

13. Gadd, G.M. (2004). Microbial influence on metal mobility and application for bioremediation. Geoderma, 122, 109-119.

14. Giller, K.E.; Witter, E.; McGrath, S.P. (1998). Toxicity of heavy metals to microorganisms and microbial processes in agricultural soils: A review. Soil Biol. Biochem., 30, 1389-1414.

15. International Programme on Chemical Safety (IPCS). (1992). Environmental Health Criteria 134: Cadmium. World Health Organization (WHO), Geneva, Switzerland.

16. International Programme on Chemical Safety (IPCS). (1992) Environmental Health Criteria 135: Cadmium: Environmental Aspect. World Health Organization (WHO), Geneva, Switzerland.

17. Iyer, A.; Mody, K.; Jha B. (2005). Biosorption of heavy metals by a marine bacterium. Marine Pol. Bull., 50, 340-343.

18. Kozdroj, J. (1995). Microbial responses to single or successive soil contamination with Cd or Cu. Soil Biol. Biochem., 27, 1459-1465.

19. Mongkolsuk, S.; Praituan, W.; Loprasert, S.; Fuangthong, M.; Chamnongpol, S. (1998). Identification and characterization of a new organic hydroperoxide resistance (ohr) gene with a novel pattern of oxidative stress regulation from Xanthomonas campestris pv. phaseoli. J. Bacteriol., 180, 2636-2643.

20. Mongkolsuk, S.; Vattanaviboon, W.; Praituan, W. (1997). Induced adaptive and cross protection responses against oxidative stress killing in a bacterial phytopathogen, Xanthomonas oryzae pv. oryzae. FEMS Microbiol Lett., 146, 217-221.

21. National Environment Committee (2005). Soil Quality Standard in Thailand. Pollution Control Department, Ministry of Natural Resources and Environment, Thailand, pp.170-181.

22. Nicholson, F.A.; Jones, K.C. (1994). Effect of phosphate fertilizers and atmospheric deposition on long-term changes in cadmium content of soils and crops. Environmental Sci. Technol., 28, 2170-2175.

23. Nies, D.H. (1992). Resistance to cadmium, cobalt, zinc and nickel in microbes. Plasmid, 27, 17-28.

24. Nies, D. H. (1995). The cobalt, zinc, and cadmium efflux system CzcABC from Alcaligenes eutrophus functions as a cation-proton antiporter in Escherichia coli. J. Bacteriol. 177, 707-2712. 
25. Nies, D.H. (1999). Microbial heavy metal resistance. Appl. Microbiol. Biotech., 51, 730-750.

26. Pichtel, J.; Kuroiwa, K.; Sawyerr, H.T. (2000). Distribution of Pb, Cd, and $\mathrm{Ba}$ in soils and plants of two contaminated sites. Environ. Poll., 110, 171-178.

27. Piotrowska-Seget, Z.; Cycon, M.; Kozdroj, J. (2005). Metal-tolerant bacteria occuring in heavily polluted soil and mine spoil. Appl. Soil Ecol., 28, 237-246.

28. Relman, D.A.; Loutit, J.S.; Schmidt, T.M.; Falkow, S.; Tompkins, L.S. (1990). The agent of bacillary angiomatosis: an approach to the identification of uncultured pathogens. New Eng. J. Med., 327, 293301.

29. Roane, T.M. (1999). Lead resistance in two bacterial isolates from heavy metal-contaminated soil. Microb. Ecol., 37, 218-224.

30. Roane, T.M.; Kellogg, S.T. (1996). Characterization of bacterial communities in heavy metal contaminated soils. Can J. Microbiol., 42, 593-603.

31. Roane, T.M.; Pepper, I.L. (2000). Microbial responses to environmentally toxic cadmium. Microb. Ecol., 38, 358-364.
32. Silver, S. (1996). Bacterial resistances to toxic metal ions-a review. Gene. 179, 9-19.

33. Stohs, S.J.; Bagchi, D. (1995). Oxidative mechanisms in the toxicity of metal ions. Free Radic. Biol. Med., 18, 321-336.

34. Taylor, M. D. (1997). Accumulation of cadmium derived from fertilisers in New Zealand soils. Sci. Total Environ., 208, 123-126.

35. Taylor, M.D.; Perciva, H.J. (2001). Cadmium in soil solutions from a transect of soils away from the fertilizer bin. Environ. Poll., 113, 35-40.

36. Vattanaviboon, P.; Praituan, W.; Mongkolsuk, S. (1995). Growth phase dependent resistance to oxidative stress in a phytopathogen Xanthomonas oryzae pv. oryzae. Can J. Microbiol., 41, 1043-1047.

37. Vattanaviboon, P.; Mongkolsuk, S. (2001). Unusual adaptive, cross protection responses and growth phase resistance against peroxide killing in a bacterial shrimp pathogen, Vibrio harveyi . FEMS Microbiol. Lett. 200, 111-116.

38. Vattanaviboon, P.; Varaluksi, T.; Mongkolsuk, S. (1999). Modulation of peroxide stress response by thiol reagents and the role of a redox sensor-transcription regulator, OxyR in mediating the response in Xanthomonas. FEMS Microbiol Lett., 176, 471-476. 